\title{
Effect of technical cashew nut shell liquid on rumen methane emission and lactation performance of dairy cows
}

\author{
A. F. Branco, ${ }^{*}$ F. Giallongo,† T. Frederick, † H. Weeks, † J. Oh,† and A. N. Hristov† \\ *Departamento de Zootecnia, Universidade Estadual de Maringá, Paraná, Brazil 87020-900 \\ †Department of Animal Science, Pennsylvania State University, University Park 16802
}

\begin{abstract}
Technical-grade cashew nut shell liquid (TCNSL) is a by-product of the cashew nut industry in tropical countries, and is known to exhibit a wide range of biological activities, including inhibitory effect against gram-positive bacteria. This study was conducted to investigate the effects of TCNSL $(73.3 \%$ cardanol, $16.4 \%$ cardol, and $3.0 \%$ methylcardol) on rumen methane emission, nutrient digestibility, dry matter intake, and milk yield and composition in dairy cows. Eight multiparous Holstein cows were used in a crossover design trial with two 21-d experimental periods. The diet was based on corn silage and alfalfa haylage and was formulated to meet or exceed the energy and metabolizable protein requirements of the cows. Treatments were control (no TCNSL supplementation) or $30 \mathrm{~g} /$ cow per day of TCNSL. Rumen carbon dioxide emission was not affected by TCNSL. Treatment had no effect on methane emission (542 vs. $511 \pm 35.3 \mathrm{~g} /$ cow per day, respectively) and methane emission intensity (15.0 vs. $13.9 \pm 0.58 \mathrm{~g} / \mathrm{kg}$ of energy-corrected milk, respectively) and tended to decrease methane emission per kilogram of dry matter intake (20.2 vs. $18.6 \pm 1.04$ $\mathrm{g} / \mathrm{kg}$, respectively). Dry matter intake (average $26.9 \pm$ $1.00 \mathrm{~kg} / \mathrm{d})$, milk yield $(40.0 \pm 1.73 \mathrm{~kg} / \mathrm{d})$, and milk composition were not different between treatments. The TCNSL had no effect on $\mathrm{N}$ losses in urine and feces and total-tract apparent digestibility of nutrients, except digestibility of neutral detergent fiber tended to be increased compared with the control. Plasma urea and glucose concentrations were not affected by TCNSL. Concentration of milk C18:0 tended to be decreased $(17 \%)$ by TCNSL compared with the control. In this study, TCNSL did not alter absolute methane emission in the rumen, but tended to decrease it by $8 \%$
\end{abstract}

Received October 24, 2014.

Accepted February 8, 2015

${ }^{1}$ Corresponding author: anh13@psu.edu per kilogram of dry matter intake. The TCNSL had no effect on milk yield and composition in dairy cows.

Key words: cashew nut shell liquid, methane, dairy cow

\section{INTRODUCTION}

Research aimed at decreasing enteric methane emissions from ruminant animals has intensified in the last decade, with a variety of mitigation practices available to the livestock industries (Hristov et al., 2013). Cashew nut shell liquid (CNSL) is a dietary supplement that has shown a potential to decrease enteric methane emission in ruminants. Studies with nonlactating dairy cattle reported up to $38 \%$ reduction in methane emission (Shinkai et al., 2012). Several earlier and more recent in vitro studies suggested that the methane mitigation effect of CNSL is likely a result of inhibition of methanogenic archaea or specific bacteria contributing methanogenic substrates by the phenol-based constituents of the product (Van Nevel et al., 1971; Danielsson et al., 2014).

Cashew nut shell liquid is a by-product of cashew nut processing and has a variety of industrial uses (Menon et al., 1985; Lubi and Thachil, 2000). Natural CNSL contains mainly 4 constituents, cardanol, cardol, anacardic acid, and 6-methyl cardol $(1.2,11.3,64.9$, and $2.0 \%$ by weight, respectively), which are mixtures of constituents differing in side-chain unsaturation (Lubi and Thachil, 2000). The antibacterial properties of anacardic acids are well known, depend on their structure, and may be species-specific (Van Nevel et al., 1971; Kubo et al., 1993). Van Nevel et al. (1971) reported that methane emission tended to decrease in vitro with increasing numbers of double bonds in the alkyl chain of anacardic acid. In view of earlier work (Demeyer and Henderickx, 1967) and results obtained by Gellerman et al. (1969), Van Nevel et al. (1971) hypothesized that anacardic acids probably exert a direct toxic effect on methanogenic archaea.

Technical-grade CNSL (TCNSL) is the most abundant industrial source of the resorcinolic lipid cardol 
and the phenolic lipid cardanol (Kozubek and Tyman, 1999). It contains little or no anacardic acids because of decarboxylation during the roasting process, which converts anacardic acid to cardanol or 2-pentadecadiethyl phenol (Tyman et al., 1978). Thus, the main active constituents of TCNSL are cardanol $(63 \%)$ and cardol (11\%), with up to $23 \%$ polymers and other minor materials (Lubi and Thachil, 2000; Voirin et al., 2014). Being phenolic acids (anacardic acid) or lipids (cardanol and cardol), these compounds have been shown to exhibit strong antibacterial, antiprotozoal, and antifungal properties (Stasiuk and Kozubek, 2010). These authors (Stasiuk and Kozubek, 2010) suggested that interactions with biological membranes and DNA structure and cytotoxic activity are responsible for the antimicrobial and antiparasitic activities of phenolic lipids, such as cardanol and cardol from TCNSL or ginkgo fruits. Cardanol has been shown to exhibit antibacterial properties against various species (Boonsai et al., 2014), although its effectiveness is considerably lower than that of anacardic acids (Himejima and Kubo, 1991). Watanabe et al. (2010), for example, reported a $57 \%$ decrease with CNSL, but only a numerical $10 \%$ reduction in methane emission in vitro with heated CNSL (i.e., TCNSL).

In vivo studies with lactating animals investigating the methane-mitigating effect of CNSL or TCNSL are scarce. Most of the data reported to date are from in vitro experiments or with nonproducing animals. To the best of our knowledge, in only one study was TCNSL tested in lactating dairy cows producing 25 to $26 \mathrm{~kg}$ milk/d (Coutinho et al., 2014). Thus, a need exists to study the effect of CNSL, and particularly TCNSL (which is more available commercially), on rumen methane emission and animal productivity in vivo in trials with high-producing animals. The hypothesis of the current experiment was that TCNSL would decrease methane emission and have no negative effects on feed intake and milk production in lactating dairy cows. The objectives of the trial were to investigate the effect of supplementation of a corn silage-based diet with $30 \mathrm{~g} /$ cow per day of TCNSL on methane and carbon dioxide emission in the rumen, nutrient digestibility, urinary and fecal N losses, milk FA profile, DMI, and milk production and composition in high-producing dairy cows.

\section{MATERIALS AND METHODS}

Animals involved in this experiment were cared for according to the guidelines of the Pennsylvania State University Animal Care and Use Committee. The committee reviewed and approved the experiment and all procedures carried out in the study.

\section{Animals and Experimental Design}

The experiment was a crossover design with 2 periods and was conducted at the tiestall facility of the Pennsylvania State University's Dairy Center. Each experimental period lasted $21 \mathrm{~d}$, with the first $14 \mathrm{~d}$ for adaptation and the last $7 \mathrm{~d}$ for sampling and data collection. The experiment was conducted with 8 multiparous Holstein dairy cows grouped in 2 treatment groups and averaging, $2.6 \pm 0.32$ lactations, $142 \pm 5.1 \mathrm{DIM}$, $40.4 \pm 1.71 \mathrm{~kg} / \mathrm{d}$ of milk yield, and $669 \pm 47.8 \mathrm{~kg}$ of BW at the beginning of the trial. The basal TMR (Table 1) was formulated to meet or exceed the $\mathrm{NE}_{\mathrm{L}}$ and $\mathrm{MP}$ requirements of the cows based on their milk production and DMI at the beginning of the trial. Treatments were control (basal TMR) and TCNSL fed at $30 \mathrm{~g} / \mathrm{cow}$ per day. The TCNSL was provided by Palmer International, Inc. (Skippack, PA) and contained cardanol $(73.3 \%)$, cardol $(16.4 \%)$, and 2-methylcardol (3.0\%). In a previous study with lactating cows, we used TCNSL application rates of up to $7 \mathrm{~g} / \mathrm{cow}$ per day (at 20 to 22 $\mathrm{kg} / \mathrm{d}$ of DMI) and did not observe any negative effects on production, DMI, or total-tract nutrient digestibility (Coutinho et al., 2014). Based on these data and the application rates of CNSL used by Shinkai et al. (2012; 20 and $37 \mathrm{~g} /$ cow per day), the $30-\mathrm{g} / \mathrm{d}$ dose was arbitrarily chosen for the current study. The $30 \mathrm{~g} / \mathrm{d}$ of TCNSL dose was close to the dose of $4 \mathrm{~g} / 100 \mathrm{~kg}$ of BW per day suggested for CNSL by Shinkai et al. (2012). Cows were fed once daily at approximately 0800 $\mathrm{h}$ and feed was offered ad libitum to achieve approximately $10 \%$ refusals. Cows were milked twice daily at approximately 0600 and $1800 \mathrm{~h}$. The TCNSL was fed top-dressed and mixed with approximately $2 \mathrm{~kg}$ of the freshly delivered TMR before cows returned from the morning milking. Feed was pushed up to the cows 4 to 6 times daily. Cows received recombinant bST (Posilac, Elanco Co., Greenfield, IN; $500 \mathrm{mg} / \mathrm{cow}$ i.m.) on d 1 and 10 of each experimental period.

\section{Sampling and Measurements}

Feed delivered and refusal weights were recorded daily. Forages were sampled weekly and dried in a microwave oven to determine DM. Weekly changes were made in the TMR if changes occurred in forage DM. Individual forage and concentrate ingredient samples were collected once weekly and samples of the TMR and refusals were collected twice weekly. Individual forage and TMR samples were composited (equal weight basis) by experimental period, dried at $65^{\circ} \mathrm{C}$ in a forcedair oven for $48 \mathrm{~h}$, and ground in a Wiley Mill (Thomas Scientific, Swedesboro, NJ) through a 1-mm sieve for further analyses. 
Table 1. Ingredient and chemical composition (\% of DM unless noted otherwise) of the basal diet fed to dairy cows

\begin{tabular}{|c|c|}
\hline Item & $\%$ of $\mathrm{DM}$ \\
\hline \multicolumn{2}{|l|}{ Ingredient composition } \\
\hline Corn silage $^{1}$ & 43.5 \\
\hline Alfalfa haylage $^{2}$ & 15.0 \\
\hline Grass hay & 4.4 \\
\hline Cottonseed, hulls & 2.2 \\
\hline Corn grain, ground & 9.0 \\
\hline Candy by-product meal ${ }^{3}$ & 5.9 \\
\hline Soybean seeds, whole, heated & 6.2 \\
\hline Canola meal, mechanically extracted & 6.1 \\
\hline Molasses & 4.2 \\
\hline Optigen $^{4}$ & 0.5 \\
\hline Mineral-vitamin premix ${ }^{5}$ & 3.0 \\
\hline \multicolumn{2}{|c|}{ Analyzed, except $\mathrm{NE}_{\mathrm{L}}$, chemical composition ${ }^{6}$} \\
\hline $\mathrm{DM}$ & 52.2 \\
\hline $\mathrm{OM}$ & 7.1 \\
\hline $\mathrm{CP}$ & 15.2 \\
\hline NDF & 31.3 \\
\hline $\mathrm{ADF}$ & 21.4 \\
\hline $\operatorname{Starch}^{7}$ & 29.8 \\
\hline $\mathrm{Ca}$ & 0.80 \\
\hline $\mathrm{P}$ & 0.34 \\
\hline $\mathrm{NE}_{\mathrm{L}},{ }^{8} \mathrm{Mcal} / \mathrm{kg}$ & 1.53 \\
\hline
\end{tabular}

${ }^{1}$ Corn silage contained (DM basis) $7.0 \% \mathrm{CP}, 41.5 \%$ starch, $33.5 \%$ $\mathrm{NDF}, 21.4 \% \mathrm{ADF}, 0.17 \% \mathrm{Ca}$, and $0.22 \% \mathrm{P}$.

${ }^{2}$ Alfalfa haylage contained (DM basis) $18.8 \%$ CP, $43.4 \%$ NDF, $37.8 \%$ $\mathrm{ADF}, 1.16 \% \mathrm{Ca}$, and $0.32 \% \mathrm{P}$.

${ }^{3}$ Candy by-product meal (Graybill Processing, Elizabethtown, PA) contained (DM basis) $17 \% \mathrm{CP}$ and $27.8 \% \mathrm{NDF}$.

${ }^{4}$ Nonprotein nitrogen source $(243.2 \%$ CP, DM basis) from Alltech Inc. (Nicholasville, KY).

${ }^{5}$ The premix (Cargill Animal Nutrition, Cargill Inc., Roaring Spring, PA) contained (\%, as-is basis) trace mineral mix, 0.86; $\mathrm{MgO}, 8.0$; $\mathrm{NaCl}, 6.4$; vitamin ADE premix (Cargill Animal Nutrition), 0.48; limestone, 37.2; selenium premix (Cargill Animal Nutrition), 0.07; and dry corn distillers grains with solubles, 46.99; Ca, 14.1\%; P, 0.39\%; $\mathrm{Mg}, 4.59 \%$; K, 0.44\%; S, 0.39\%; Se, $6.91 \mathrm{mg} / \mathrm{kg}$; Cu, $362 \mathrm{mg} / \mathrm{kg}$; Zn, $1,085 \mathrm{mg} / \mathrm{kg} ; \mathrm{Fe}, 186 \mathrm{mg} / \mathrm{kg}$, vitamin A, 276,717 IU $/ \mathrm{kg}$; vitamin D, $75,000 \mathrm{IU} / \mathrm{kg}$; and vitamin E, 1,983 IU/kg.

${ }^{6}$ Analyzed by Cumberland Valley Analytical Services (Maugansville, MD) using wet chemistry methods.

${ }^{7}$ Analyzed according to Bach Knudsen (1997).

${ }^{8}$ Estimated based on NRC (2001).

Spot urine (approximately $500 \mathrm{~mL} /$ sample) and fecal (approximately $400 \mathrm{~g} /$ sample) samples were collected on 3 consecutive days during wk 3 of each experimental period at 1000, 1600, and $2200 \mathrm{~h} \mathrm{(d} \mathrm{1);0400,1300,} \mathrm{and}$ $1900 \mathrm{~h} \mathrm{(d} \mathrm{2);} \mathrm{and} 0100$ and $0800 \mathrm{~h}$ (d 3). Urine samples were collected by massaging the vulva. Fecal samples were collected by stimulating defecation, or from the rectum. Fecal samples were oven-dried at $65^{\circ} \mathrm{C}$ and composited per cow and period on an equal DM basis. Fresh fecal samples from each cow were composited on an equal wet basis by cow and period and frozen immediately at $-20^{\circ} \mathrm{C}$ for later analysis. Urine samples were acidified with $2 \mathrm{M} \mathrm{H}_{2} \mathrm{SO}_{4}$ to a $\mathrm{pH}<3.0$, diluted 1:10 with distilled water, and stored frozen $\left(-20^{\circ} \mathrm{C}\right)$ for later analysis.
Rumen methane and carbon dioxide emission were measured during the last week of each experimental period using GreenFeed (C-Lock Technology Inc., Rapid City, SD). GreenFeed is an automated system to monitor gas mass fluxes from the breath of ruminant animals (Zimmerman et al., 2011). For this trial, one GreenFeed unit was used. The unit was positioned in the feed bunk in front of each cow starting at 0900, 1500 , and 2100 (d 1), 0300, 1200, and 1700 (d 2), and 0000 , and $0500 \mathrm{~h} \mathrm{(d} \mathrm{3)} \mathrm{during} \mathrm{the} \mathrm{last} \mathrm{wk} \mathrm{of} \mathrm{each} \mathrm{ex-}$ perimental period. Breath gas samples were collected for 5 min followed by a 2-min background gas sample collection. The GreenFeed unit was calibrated 3 to 4 times before and 3 to 4 times after each sampling period with a standard carbon dioxide and methane gas mixture containing (mol \%) carbon dioxide (0.98) and methane (0.151), with the balance being $\mathrm{N}$ gas (Air Liquide America Specialty Gases LLC, Houston, TX). The bait feed used was a premix containing (as-is basis): $70 \%$ ground corn grain, $28 \%$ dried molasses, and $2 \%$ soybean oil. Cows received approximately $280 \mathrm{~g}$ of bait feed during each sampling event (i.e., a total of 280 $\times 8=2,240 \mathrm{~g} /$ cow during each sampling period).

Blood samples were collected from the tail vein or artery $2 \mathrm{~h}$ after feeding on 2 consecutive days during wk 3 of each experimental period. Cows were weighed daily using the Afifarm 3.04E scale system (S.A.E. Afikim, Rehovot, Israel) while they exited the milking parlor. Milk production was recorded daily. Milk samples were collected from consecutive morning and evening milkings during wk 3 of each experimental period. Samples for milk composition were preserved with 2-bromo-2-nitropropane-1,3 diol for later analyses. Separate samples were collected for FA analysis. These samples were immediately centrifuged at $3,000 \times g$ for $30 \mathrm{~min}$ at $4^{\circ} \mathrm{C}$ and the fat cake was stored at $-20^{\circ} \mathrm{C}$ for later analysis.

\section{Analytical Procedures}

Dry matter intake was calculated by adjusting daily as-fed feed intake to DM percentage of the weekly TMR and refusal composite samples. Dried and ground TMR were submitted to Cumberland Valley Analytical Services (Maugansville, MD) for wet chemistry analyses of $\mathrm{CP}, \mathrm{NDF}, \mathrm{ADF}, \mathrm{Ca}$, and $\mathrm{P}$ [details at: http:// www.foragelab.com/Resources/Lab-Procedures; AOAC International (2000) procedures 990.03, 973.18, and 985.01 for $\mathrm{CP}, \mathrm{ADF}$, and $\mathrm{Ca}$ and $\mathrm{P}$, respectively, and Van Soest et al. (1991) for NDF].

Diluted urine samples were analyzed for allantoin (Chen et al., 1992), uric acid (Stanbio Uric Acid Kit 1045; Stanbio Laboratory Inc., San Antonio, TX), urea N (Stanbio Urea Nitrogen Kit 580; Stanbio Labora- 
tory Inc.), and creatinine (Stanbio Creatinine Kit 0400; Stanbio Laboratory Inc.). Daily urine volume and excretion of urea $\mathrm{N}$ and total $\mathrm{N}$ were estimated from urinary creatinine concentration, assuming a creatinine excretion rate of $29 \mathrm{mg} / \mathrm{kg}$ of BW (Hristov et al., 2011). Excretion of urinary purine derivatives (allantoin and uric acid) was used to estimate microbial $\mathrm{N}$ outflow from the rumen as described in Hristov et al. (2009). A ratio of purine $\mathrm{N}$ to total $\mathrm{N}$ in rumen microorganisms of 0.134 was assumed based on the data of Valadares et al. (1999). Nitrogen content for feces and urine were analyzed on a Costech ECS $4010 \mathrm{C} / \mathrm{N} / \mathrm{S}$ elemental analyzer (Costech Analytical Technologies Inc., Valencia, CA) and multiplied by 6.25 to obtain CP. Fecal samples were pulverized at $30 \mathrm{~Hz} / \mathrm{s}$ for 2 min using a Mixer Mill MM 200 (Retsch GmbH, Haan, Germany) before the $\mathrm{N}$ analysis. Feed and fecal samples were ashed for $4 \mathrm{~h}$ at $600^{\circ} \mathrm{C}$ for $\mathrm{OM}$ determination. Samples of TMR and feces were analyzed for starch (Bach Knudsen, 1997).

Fecal composited samples were analyzed for NDF and ADF using Ankom A200 apparatus (Ankom Technology, Macedon, NY) according to Van Soest et al. (1991) with heat-stable amylase (Ankom Technology) and sodium sulfite (Fisher Scientific, Waltham, MA) used in the NDF procedure. Indigestible NDF was used as a digestibility marker (Schneider and Flatt, 1975) and was analyzed following a procedure described by Huhtanen et al. (1994; 288-h in situ incubation) with the modification that $25-\mu \mathrm{m}$ porosity filter bags (Ankom Technology) were used. Bag and residues were analyzed for NDF as described previously.

Fresh fecal samples were frozen immediately at $-20^{\circ} \mathrm{C}$. These samples were composited (on an equal wet weight basis) per cow and period and analyzed for bacterial genera and species distribution. The $16 \mathrm{~S}$ rRNA gene V4 variable region PCR primers 515/806 (Caporaso et al., 2011) were used in a single-step 30-cycle PCR using the HotStarTaq Plus Master Mix Kit (Qiagen, Germantown, MD) under the following conditions: $94^{\circ} \mathrm{C}$ for $3 \mathrm{~min}$, followed by 28 cycles $(5$ cycles used on PCR products) of $94^{\circ} \mathrm{C}$ for $30 \mathrm{~s}, 53^{\circ} \mathrm{C}$ for $40 \mathrm{~s}$, and $72^{\circ} \mathrm{C}$ for $1 \mathrm{~min}$, after which a final elongation step at $72^{\circ} \mathrm{C}$ for 5 min was performed. Sequencing was performed at Molecular Research DNA (www.mrdnalab.com; Shallowater, TX) on an Ion Torrent PGM following the manufacturer's guidelines. Sequence data were processed using a proprietary analysis pipeline (Molecular Research DNA). In summary, sequences were depleted of barcodes and primers, then sequences $<150$ bp were removed, and sequences with ambiguous base calls and with homopolymer runs exceeding 6 bp were also removed. Sequences were denoised, operational taxonomic units were generated, and chimeras were removed. Operational taxonomic units were defined by clustering at $3 \%$ divergence ( $97 \%$ similarity). Final operational taxonomic units were taxonomically classified using BLASTn (Nucleotide-nucleotide Basic Local Alignment Search Tool) against a curated database derived from GreenGenes, RDPII, and NCBI (http://rdp.cme.msu.edu; DeSantis et al., 2006; www. ncbi.nlm.nih.gov).

Blood samples were centrifuged at $1,500 \times g$ for 20 min at $4^{\circ} \mathrm{C}$ and frozen at $-40^{\circ} \mathrm{C}$ for later analysis of BUN (Stanbio Urea Nitrogen Kit 580; Stanbio laboratory Inc.) and glucose (Stanbio Glucose kit 1075; Stanbio Laboratory Inc.). Samples were composited on an equal volume base for these analyses.

Morning and evening milk samples were analyzed separately so milk component concentration and yield could be weighted for morning and evening milk yields. Milk samples were analyzed for fat, protein, lactose, and MUN (Pennsylvania DHIA, University Park, PA). Fat, true protein, lactose, and MUN were determined using infrared spectroscopic method (MilkoScan 4000, Foss Electric, Hillerød, Denmark).

Milk fat samples for FA analysis were thawed at room temperature in water, pooled within day, and analyzed for FA composition as described by Rico and Harvatine (2013). Briefly, milk lipids were extracted with hexaneisopropanol and transmethylated in the presence of sodium methoxide. Quantification of FAME was performed by GC with a flame ionization detector and a capillary column $(\mathrm{SP}-2560 ; 100 \mathrm{~m} \times 0.25 \mathrm{~mm}$ i.d. with $0.2-\mu \mathrm{m}$ film thickness; Supelco Inc. Bellefonte, PA). The initial oven temperature was $80^{\circ} \mathrm{C}$, was increased by $2^{\circ} \mathrm{C} / \mathrm{min}$ to $190^{\circ} \mathrm{C}$ and held for $15 \mathrm{~min}$, and then increased by $8^{\circ} \mathrm{C} / \mathrm{min}$ to $215^{\circ} \mathrm{C}$ and held for $17 \mathrm{~min}$. Last, when separation of trans-10 C18:1 and trans-11 $\mathrm{C} 18: 1$ was not achieved, a second $165^{\circ} \mathrm{C}$ isothermal run was conducted to quantify these isomers.

The chemical composition of CNSL was determined by GC-MS, performed on a Shimadzu GCMSQP2010 Ultra System (Shimadzu Scientific Instruments, Columbia, MD), equipped with an AOC-20i auto-injector. The column used was a Restek RTX-5ms (30 m, 0.25 mm i.d., $0.25 \mu \mathrm{m}$ df; Restek Corp., Bellefonte, PA), coated with $5 \%$ diphenyl-95\% polydimethylsiloxane, operated with the following oven temperature program: $50^{\circ} \mathrm{C}$, rising at $10^{\circ} \mathrm{C} / \mathrm{min}$ to $200^{\circ} \mathrm{C}$, rising at $2^{\circ} \mathrm{C} / \mathrm{min}$ to $320^{\circ} \mathrm{C}$; injection temperature and volume $=250^{\circ} \mathrm{C}$ and $1.0 \mu \mathrm{L}$, respectively; injection mode $=$ splitless; carrier gas $=\mathrm{He}$; ion source $=300^{\circ} \mathrm{C}$.

Composited milk and blood plasma samples were analyzed for oxidative stress markers. Thiobarbituric acid reactive substances and 8-isoprostane were analyzed using ELISA kits (Cayman Chemical, Ann Arbor, MI) 
and oxygen radical absorbance capacity was analyzed as trolox equivalents as described elsewhere (Cao and Prior, 1999).

\section{Statistical Analysis}

All data were analyzed using the MIXED procedure of SAS (SAS Institute Inc., Cary, NC) assuming a crossover design. Cow was the experimental unit. With the exception of milk yield, DMI, and feed efficiency (milk yield/DMI), data collected at multiple time points (rumen gas emission, urine and fecal data, and so on) were averaged per cow and period and the average values were used in the statistical analysis. The averaged milk composition values and averaged milk yield and DMI during the last week of each experimental period were used to calculate milk fat, protein, and lactose yields. Body weight data for 3 consecutive days at the beginning of the trial, at the start of the second experimental period, and end of the trial were used in the statistical analysis. The statistical model included treatment, period, and treatment $\times$ period interaction. Cow within group was a random effect and all others were fixed. All data were analyzed for normal distribution using the UNIVARIATE procedure of SAS. The null hypothesis of normality was rejected (i.e., $P<0.05$ and small Shapiro-Wilk $W$ statistic) for 8 -isoprostane in milk and plasma thiobarbituric acid reactive substances. These data were log-transformed and the transformed data were analyzed statistically. Dry matter intake, milk yield, and feed efficiency data from wk 3 of each experimental period were analyzed as repeated measures assuming an autoregressive first order $[\mathrm{AR}(1)]$ covariance structure. The model included treatment, period, day of measurement, and treatment $\times$ period and treatment $\times$ day interactions. Statistical differences were declared at $P<0.05$. Differences between treatments with $0.05 \leq P \leq 0.10$ were considered as a trend toward significance. Data are presented as least squares means.

\section{RESULTS AND DISCUSSION}

Emission of carbon dioxide, total or per unit of DMI or milk yield was not affected by TCNSL in this experiment (Table 2). It is noted that carbon dioxide measured by GreenFeed (or other methods used in animal science) is primarily from respiratory metabolism and, therefore, differences in rumen carbon dioxide emission among treatments may be masked by the larger respiratory carbon dioxide pool. Total methane emission was also not different between treatments, but tended to be lower (by $8 \% ; P=0.10$ ) compared with the control when calculated per unit of DMI. Methane emission per kilogram of ECM was numerically lower (by about $7 \% ; P=0.11$ ) for TCNSL versus the control. We have to point out, however, that these subtle effects of TCNSL on methane emission occurred in relatively short experimental periods. The critical need for longterm trials with methane mitigation compounds or practices has been discussed (Hristov et al., 2013) and was not addressed in the current study. With only $21-d$ experimental periods, the current study cannot claim that the observed trends for reduced methane emission by TCNSL are permanent and not temporary.

Earlier in vitro work demonstrated a strong antimicrobial and antimethanogenic effect of anacardic acids (Demeyer and Henderickx, 1967; Gellerman et al. 1969; Van Nevel et al., 1971). The interest in CNSL as an methane-mitigating agent was renewed by Watanabe et al. (2010), who reported a $57 \%$ reduction in methane emission in vitro by raw CNSL (containing about $58 \%$

Table 2. Methane and $\mathrm{CO}_{2}$ emissions ${ }^{1}$ in dairy cows fed a control or a TCNSL ${ }^{2}$-supplemented diet (LSM)

\begin{tabular}{lcccc}
\hline Item & Control & TCNSL & SEM $^{3}$ & $P$-value \\
\hline $\mathrm{CO}_{2}, \mathrm{~g} / \mathrm{d}$ & 17,167 & 16,807 & 588.3 & 0.58 \\
$\mathrm{CO}_{2},{ }_{4} \mathrm{~g} / \mathrm{kg}$ of DMI & 639 & 617 & 13.1 & 0.36 \\
$\mathrm{CO}_{2},{ }_{4}$ g/kg of milk & 418 & 415 & 32.9 & 0.89 \\
$\mathrm{CO}_{2}, \mathrm{~g} / \mathrm{kg}$ of ECM & 479 & 459 & 20.5 & 0.28 \\
$\mathrm{CH}_{4}, \mathrm{~g} / \mathrm{d}$ & 542 & 511 & 35.3 & 0.20 \\
$\mathrm{CH}_{4},{ }_{4} \mathrm{~g} / \mathrm{kg}$ of DMI & 20.2 & 18.6 & 1.04 & 0.10 \\
$\mathrm{CH}_{4}, \mathrm{~g} / \mathrm{kg}$ of milk & 13.6 & 12.7 & 1.28 & 0.21 \\
$\mathrm{CH}_{4}, \mathrm{~g} / \mathrm{kg}$ of ECM & 15.0 & 13.9 & 0.58 & 0.11 \\
\hline
\end{tabular}

${ }^{1}$ Rumen gas emissions were measured using GreenFeed (C-Lock Technology Inc., Rapid City, SD). Data were derived from 8 individual measurements staggered over a 3-d period (for details, see Materials and Methods).

${ }^{2}$ TCNSL (technical-grade cashew nut shell liquid) $=30 \mathrm{~g} /$ cow per day.

${ }^{3}$ Largest SEM published in table, $\mathrm{n}=14$ ( $\mathrm{n}$ represents number of observations used in statistical analysis).

${ }^{4}$ Based on milk yield and DMI data during the gas measurement periods.

${ }^{5}$ Calculated according to Sjaunja et al. (1990). 
anacardic acid and applied at up to $500 \mu \mathrm{g} / \mathrm{mL}$ of incubation medium), but only a numerical $10 \%$ reduction by TCNSL (containing $72 \%$ cardanol, but no anacardic acid). Compared with the control, both compounds increased propionate production (Watanabe et al., 2010). A later study by Shinkai et al. (2012) reported a $38 \%$ reduction in methane emission and a corresponding increase in rumen propionate in nonlactating dairy cows fed a $60 \%$ hay and $40 \%$ concentrate diet supplemented with $4 \mathrm{~g}$ of CNSL/100 $\mathrm{kg}$ of BW. In that study, it appeared that CNSL inhibited the expression of methyl coenzyme-M reductase, a key enzyme in methane synthesis by methanogenic archaea in the rumen (Wolfe, 1991). More recently, Mitsumori et al. (2014) reported similar inhibitory effect of 3 to $4 \mathrm{~g}$ of CNSL/100 $\mathrm{kg}$ of BW on methane emission in nonlactating Holstein cows and also observed increased propionate and hydrogen gas emission. In studies by Shinkai et al. (2012) and Mitsumori et al. (2014), CNSL was included in the ration as a pelleted product. Pelleting produces heat, and heat converts anacardic acid into cardanol (Tyman et al., 1978), but the effect of pelleting CNSL on its anacardic acid content was not reported by these authors. Himejima and Kubo (1991) investigated the antibacterial properties of CNSL and heated CNSL (i.e., TCNSL) and found a significant drop in MIC for some bacteria-Brevibacterium ammoniagenes and Staphylococcus aureus, for example - but not for others (Bacillus subtilis and Streptococcus mutans). Other studies have also shown antimicrobial properties of cardol or cardanol, although not as strong as those of anacardic acid (Himejima and Kubo, 1991; Boonsai et al., 2014). In a study with natural phenolic compounds, Yoon and Kim (2009) reported antibiofouling activities of both anacardic acid and cardanol (extracted from CNSL) against Pseudomonas fluorescens. Both compounds killed all cells within 18 (anacardic acid) and $30 \mathrm{~h}$ (cardanol) after addition to the culture. Thus, it is apparent that anacardic acids are responsible for most of the antimicrobial activities reported for natural CNSL. The major compounds in TCNSL (cardol and cardanol), however, also have antibacterial, antiprotozoal, and antifungal properties (Stasiuk and Kozubek, 2010). This, combined with the abundance of TCNSL, due to its industrial applications, make it an attractive methane mitigation agent.

A recent study with lambs by El-Zaiat et al. (2014) reported no additive effect of CNSL (about $49 \%$ anacardic acid and 39\% cardanol) and nitrate on methane emission or propionate concentration. In that study, CNSL was supplemented at about $0.14 \%$ of dietary DM (which is comparable to the application rate of TCNSL in the current experiment). Neither treatment had an effect on DMI, growth rate, or feed efficiency of the lambs. In vitro, a CNSL extract product (produced by the authors with unknown ingredient composition) had no effect (applied at $83 \mu \mathrm{g} / \mathrm{mL}$ ) or reduced methane emission by $18 \%$ when applied at $166 \mu \mathrm{g} / \mathrm{mL}$ (Danielsson et al., 2014). That study also reported a shift in rumen bacterial and archaeal populations with the higher CNSL extract application rate clustering with Barnesiella, unclassified Porphyromonadaceae, and Succiniclasticum.

Intake of nutrients was not different between diets in the current experiment (Table 3). Also, no difference was observed in apparent total-tract digestibility of nutrients, except that NDF digestibility tended to be increased $(P=0.09)$ by TCNSL. Populations of the most prevalent genus of fecal bacteria were not affected by TCNSL (Table 4). Compared with the control, TCNSL decreased or tended to decrease the proportions of Butyrivibrio, Barnesiella, and Odoribacter $(P=$ $0.02,0.08$, and 0.07 , respectively) and increased $(P=$ 0.03 ) that of Succinivibrio. Rumen contents could not be sampled in the current study and, therefore, fecal samples were used to derive some information on the effect of TCNSL on rumen bacteria. Nitrogen intake, urinary total-, urea-, and fecal-N excretions, milk protein $\mathrm{N}$ secretion, urinary purine derivatives excretion (and the estimated microbial $\mathrm{N}$ synthesis in the rumen), and plasma urea $\mathrm{N}$ were not affected by TCNSL (Table 5).

Dry matter intake, milk yield, milk composition, ECM, milk $\mathrm{NE}_{\mathrm{L}}$, and cow $\mathrm{BW}$ were unaffected by TCNSL (Table 6). Milk yield was numerically greater $(P=0.13)$ for TCNSL compared with the control. Concentration of MUN was increased (by $14 \% ; P=0.03$ ) by TCNSL.

Very little data exists on the effect of CNSL or TCNSL on digestibility, urinary or fecal $\mathrm{N}$ excretion, and milk production in dairy cows, and no data exists on high-producing animals. In one of the experiments of Shinkai et al. (2012), total-tract digestibility of dietary DM and energy were decreased by CNSL. In a recent study, Coutinho et al. (2014) reported that TCNSL (73.3\% cardanol, $16.4 \%$ cardol, and $3.0 \%$ methylcardol) supplemented to the diet of dairy cows (up to $0.036 \%$ of DM, or $7 \mathrm{~g} / \mathrm{d}$ ) had no effect on DMI, apparent totaltract digestibility of nutrients, FCM yield, and milk composition (milk production of the cows was 25 to 26 $\mathrm{kg} / \mathrm{d})$.

Odd- and branched-chain milk FA have been proposed as biomarkers of microbial synthesis or methane emission in the rumen (Vlaeminck et al., 2006; Dijkstra et al., 2011; Fievez et al., 2012). A recent meta-analysis pointed out several relatively weak (or "moderately strong," as termed by the authors) relationships be- 
Table 3. Nutrient intakes and apparent total-tract digestibilities in dairy cows fed a control or a TCNSL ${ }^{1}$ supplemented diet (LSM)

\begin{tabular}{lcccc}
\hline Item & Control & TCNSL $^{1}$ & SEM $^{2}$ & $P$-value \\
\hline Intake $^{3} \mathrm{~kg} / \mathrm{d}$ & & & & \\
OM & 24.7 & 25.7 & 0.80 & 0.24 \\
CP & 4.0 & 4.2 & 0.14 & 0.25 \\
NDF & 8.5 & 8.9 & 0.28 & 0.23 \\
ADF & 5.3 & 5.5 & 0.18 & 0.25 \\
Starch & 7.9 & 8.2 & 0.26 & 0.27 \\
Apparent total-tract digestibility, $\%$ & 61.9 & 62.7 & 0.77 & 0.25 \\
DM & 63.0 & 63.8 & 0.77 & 0.20 \\
OM & 60.2 & 59.8 & 1.26 & 0.86 \\
CP & 34.2 & 36.8 & 1.47 & 0.09 \\
NDF & 28.7 & 29.5 & 1.91 & 0.63 \\
ADF & 97.8 & 97.7 & 0.10 & 0.60 \\
Starch & 30.7 & & \\
\hline
\end{tabular}

${ }^{1}$ TCNSL (technical-grade cashew nut shell liquid) $=30 \mathrm{~g} / \mathrm{cow}$ per day.

${ }^{2} \mathrm{n}=16$ ( $\mathrm{n}$ represents number of observations used in statistical analysis).

${ }^{3} \mathrm{DMI}$ is shown in Table 6 .

tween milk FA and rumen methane emission (van Lingen et al., 2014). Therefore, it is of interest to monitor milk FA profile in experiments aimed at rumen methane mitigation. Milk FA composition data from the current experiment are shown in Table 7. Overall, the effect of TCNSL on milk FA was subtle, except a trend for a $17 \%$ reduction in $\mathrm{C} 18: 0(P=0.06)$. The concentration of C4:0 was also decreased $(P=0.02)$ and that $\mathrm{C} 14: 0$ iso was numerically decreased $(P=0.11)$ by TCNSL compared with the control. A numerical increase $(P=$
0.11) as a result of TCNSL supplementation of the diet was observed for C13:0. To the best of our knowledge, only one other study, that of Coutinho et al. (2014), reported milk FA data for lactating cows receiving TCNSL. In that study, the authors observed a linear decrease in $\mathrm{C} 6: 0$, a quadratic response in $\mathrm{C} 13: 1 \mathrm{n}-5$, and a linear increase in $\mathrm{C} 16: 1 \mathrm{n}-7$ concentrations. The milk FA data from the current experiment are difficult to interpret without having rumen fermentation data. Of the milk FA affected by TCNSL in the current study,

Table 4. Fecal bacterial populations in dairy cows fed a control or a TCNSL $^{1}$-supplemented diet (LSM; percentage $^{2}$ of total isolates)

\begin{tabular}{|c|c|c|c|c|}
\hline Item & Control & TCNSL & $\mathrm{SEM}^{3}$ & $P$-value \\
\hline \multicolumn{5}{|l|}{ Family } \\
\hline Ruminococcaceae & 48.0 & 45.0 & 3.00 & 0.51 \\
\hline Peptostreptococcaceae & 4.72 & 5.37 & 1.31 & 0.66 \\
\hline Prevotellaceae & 3.61 & 3.58 & 0.31 & 0.89 \\
\hline \multicolumn{5}{|l|}{ Genus } \\
\hline Bifidobacterium & 5.35 & 7.03 & 2.59 & 0.62 \\
\hline Bacteroides & 5.93 & 5.70 & 0.76 & 0.79 \\
\hline Ruminococcus & 3.59 & 3.57 & 0.28 & 0.96 \\
\hline Alistipes & 3.31 & 3.05 & 0.20 & 0.24 \\
\hline Coprococcus & 2.37 & 2.58 & 0.27 & 0.57 \\
\hline Pseudobutyrivibrio & 2.57 & 1.86 & 0.67 & 0.47 \\
\hline Clostridium & 1.79 & 2.03 & 0.26 & 0.42 \\
\hline Turicibacter & 1.21 & 1.57 & 0.54 & 0.40 \\
\hline Blautia & 1.17 & 1.51 & 0.16 & 0.12 \\
\hline Barnesiella & 1.26 & 1.00 & 0.09 & 0.08 \\
\hline Methanobrevibacter & 0.92 & 1.10 & 0.17 & 0.25 \\
\hline Treponema & 0.90 & 1.05 & 0.27 & 0.32 \\
\hline Dermatophilus & 1.09 & 0.82 & 0.11 & 0.10 \\
\hline Fecalibacterium & 0.68 & 1.04 & 0.19 & 0.29 \\
\hline Butyrivibrio & 0.59 & 0.48 & 0.08 & 0.02 \\
\hline Succinivibrio & 0.16 & 0.30 & 0.04 & 0.03 \\
\hline Odoribacter & 0.11 & 0.08 & 0.02 & 0.07 \\
\hline
\end{tabular}

${ }^{1}$ TCNSL (technical-grade cashew nut shell liquid) $=30 \mathrm{~g} /$ cow per day.

${ }^{2}$ Represents percentage of the total sequences analyzed within the sample.

${ }^{3} \mathrm{n}=16$ (n represents number of observations used in statistical analysis). 
Table 5. Urinary purine derivatives (PD) and $\mathrm{N}$ excretion and secretion in dairy cows fed a control or a TCNSL ${ }^{1}$-supplemented diet (LSM)

\begin{tabular}{|c|c|c|c|c|}
\hline Item & Control & TCNSL & $\mathrm{SEM}^{2}$ & $P$-value \\
\hline $\mathrm{N}$ intake, $\mathrm{g} / \mathrm{d}$ & 646 & 673 & 27.3 & 0.24 \\
\hline \multicolumn{5}{|l|}{ Urinary and fecal excretions } \\
\hline Urine output, $\mathrm{kg} / \mathrm{d}$ & 15.5 & 16.2 & 1.20 & 0.57 \\
\hline Urine $\mathrm{N}, \mathrm{g} / \mathrm{d}$ & 151 & 160 & 8.3 & 0.50 \\
\hline$\%$ of $\mathrm{N}$ intake & 23.5 & 23.7 & 1.13 & 0.88 \\
\hline Urea N, g/d & 81.3 & 93.3 & 6.30 & 0.27 \\
\hline Fecal N, g/d & 257 & 272 & 15.0 & 0.39 \\
\hline$\%$ of $\mathrm{N}$ intake & 39.8 & 40.2 & 1.26 & 0.86 \\
\hline Urinary and fecal $\mathrm{N}$ excretion, $\mathrm{g} / \mathrm{d}$ & 408 & 432 & 20.9 & 0.43 \\
\hline$\%$ of intake & 63.3 & 63.9 & 1.87 & 0.86 \\
\hline Milk protein $\mathrm{N}, \mathrm{g} / \mathrm{d}$ & 190 & 197 & 8.93 & 0.49 \\
\hline$\%$ of $\mathrm{N}$ intake & 29.5 & 29.5 & 0.95 & 0.97 \\
\hline \multicolumn{5}{|l|}{ Urinary PD excretion, $\mathrm{mmol} / \mathrm{d}$} \\
\hline Allantoin & 557 & 561 & 31.2 & 0.95 \\
\hline Uric acid & 70.6 & 72.2 & 6.73 & 0.78 \\
\hline Total PD & 627 & 633 & 34.7 & 0.93 \\
\hline Microbial N synthesis in the rumen, ${ }^{3} \mathrm{~g} / \mathrm{d}$ & 536 & 541 & 32.2 & 0.93 \\
\hline $\mathrm{PUN},{ }^{4} \mathrm{mg} / \mathrm{dL}$ & 9.1 & 9.2 & 0.44 & 0.92 \\
\hline Blood glucose, mg/dL & 77.9 & 81.2 & 2.70 & 0.45 \\
\hline
\end{tabular}

${ }^{1}$ TCNSL (technical-grade cashew nut shell liquid) $=30 \mathrm{~g} /$ cow per day.

${ }^{2} \mathrm{n}=16$ (n represents number of observations used in statistical analysis).

${ }^{3}$ Estimated based on urinary PD excretion (see Materials and Methods).

${ }^{4}$ Plasma urea $\mathrm{N}$.

only C14:0 iso was also found to be positively related to methane emission by van Lingen et al. (2014).

Concentration of oxidative status (anti- or pro-oxidant) markers in milk and plasma was not affected by TCNSL (Table 8 ). There was a numerical, $12 \%$ increase $(P=0.14)$ in the trolox equivalent antioxidant capacity of milk from the TCNSL-treated cows compared with milk from the control cows. Anacardic acid and both cardol and cardanol have strong antioxidant properties and by-products of the cashew nut industry, such as CNSL and cashew fiber, have been recommended as anticancer agents (Trevisan et al., 2006). A recent review by Voirin et al. (2014) offered extensive evidence of the antioxidant properties of cardanol, cardol, and their derivatives. The antioxidant capacity of anacardic acid, however, is reportedly much greater (6 to 14 times; Trevisan et al., 2006) than that of cardol and cardanol and the lack of effect on antioxidant markers in milk and plasma in the current trial is likely due to the absence of anacardic acid in the TCNSL product.

Table 6. Dry matter intake, milk yield, milk composition, and BW in dairy cows fed a control or a TCNSLsupplemented $\operatorname{diet}^{1}(\mathrm{LSM})$

\begin{tabular}{lcccc}
\hline Item & Control & TCNSL & SEM $^{2}$ & $P$-value \\
\hline DMI, kg/d & 26.5 & 27.3 & 1.00 & 0.30 \\
Milk yield, kg/d & 39.0 & 40.9 & 1.73 & 0.13 \\
Milk yield/DMI, kg/kg & 1.49 & 1.51 & 0.06 & 0.55 \\
Milk fat, \% & 3.35 & 3.28 & 0.28 & 0.74 \\
kg/d & 1.29 & 1.35 & 0.14 & 0.59 \\
Milk true protein, \% & 3.10 & 3.08 & 0.05 & 0.62 \\
kg/d & 1.21 & 1.26 & 0.07 & 0.49 \\
Milk lactose, \% & 4.68 & 4.68 & 0.06 & 0.91 \\
kg/d & 1.83 & 1.91 & 0.16 & 0.38 \\
MUN, mg/dL & 7.50 & 8.57 & 0.62 & 0.03 \\
ECM, ${ }^{3}$ kg/d & 35.1 & 36.5 & 1.65 & 0.46 \\
BW, ${ }^{2} \mathrm{~kg}$ & 672 & 676 & 4.37 & 0.48 \\
\hline
\end{tabular}

${ }^{1}$ DMI and milk production and composition data are from wk 3 of each experimental period; TCNSL (technical-grade cashew nut shell liquid) $=30 \mathrm{~g} / \mathrm{cow}$ per day.

${ }^{2}$ DMI, $\mathrm{n}=112$; milk yield, $\mathrm{n}=104$; milk yield/DMI, $\mathrm{n}=104$; others, $\mathrm{n}=16$ ( $\mathrm{n}$ represents number of observations used in statistical analysis).

${ }^{3}$ Calculated according to Sjaunja et al. (1990).

${ }^{4}$ Average BW during the trial. 
Table 7. Fatty acid composition of milk fat in dairy cows fed a control or a TCNSL ${ }^{1}$-supplemented diet (LSM)

\begin{tabular}{|c|c|c|c|c|}
\hline FA $(g / 100 \mathrm{~g}$ of $\mathrm{FA})$ & Control & TCNSL & $\mathrm{SEM}^{2}$ & $P$-value \\
\hline 4:0 & 4.22 & 3.69 & 0.147 & 0.02 \\
\hline $6: 0$ & 2.16 & 1.97 & 0.131 & 0.21 \\
\hline $8: 0$ & 1.17 & 1.15 & 0.106 & 0.90 \\
\hline 10:0 & 2.62 & 2.84 & 0.322 & 0.54 \\
\hline $11: 0$ & 0.06 & 0.09 & 0.015 & 0.16 \\
\hline $12: 0$ & 3.12 & 3.57 & 0.372 & 0.29 \\
\hline 13:0 & 0.11 & 0.14 & 0.017 & 0.11 \\
\hline $14: 0$ & 10.1 & 10.8 & 0.599 & 0.32 \\
\hline 14:0 iso & 0.09 & 0.06 & 0.017 & 0.11 \\
\hline $14: 1$ & 0.98 & 1.07 & 0.103 & 0.39 \\
\hline $15: 0$ & 0.98 & 1.11 & 0.076 & 0.15 \\
\hline 15:0 iso & 0.15 & 0.14 & 0.008 & 0.22 \\
\hline 15:0 anteiso & 0.35 & 0.34 & 0.009 & 0.51 \\
\hline $16: 0$ & 25.7 & 24.1 & 1.012 & 0.18 \\
\hline 16:0 iso & 0.18 & 0.16 & 0.032 & 0.60 \\
\hline $16: 1$ & 1.50 & 1.58 & 0.204 & 0.69 \\
\hline $17: 0$ & 0.47 & 0.49 & 0.022 & 0.57 \\
\hline 17:0 isso & 0.25 & 0.25 & 0.016 & 0.69 \\
\hline 17:0 anteiso & 0.32 & 0.34 & 0.026 & 0.47 \\
\hline $17: 1$ & 0.18 & 0.22 & 0.021 & 0.20 \\
\hline 18:0 & 11.5 & 9.52 & 0.817 & 0.06 \\
\hline trans-4 18:1 & 0.03 & 0.03 & 0.002 & 0.65 \\
\hline trans-5 18:1 & 0.03 & 0.03 & 0.003 & 0.45 \\
\hline trans-6,8 18:1 & 0.49 & 0.61 & 0.114 & 0.35 \\
\hline trans-9 18:1 & 0.36 & 0.45 & 0.080 & 0.31 \\
\hline trans-10 18:1 & 1.29 & 2.14 & 0.886 & 0.39 \\
\hline trans-11 18:1 & 1.03 & 1.13 & 0.197 & 0.64 \\
\hline trans-12 18:1 & 0.67 & 0.69 & 0.055 & 0.71 \\
\hline cis-9 18:1 & 20.1 & 20.6 & 0.648 & 0.52 \\
\hline cis-11 18:1 & 0.86 & 1.05 & 0.113 & 0.15 \\
\hline cis-12 18:1 & 0.53 & 0.60 & 0.071 & 0.40 \\
\hline Linoleic acid & 3.22 & 3.42 & 0.226 & 0.42 \\
\hline cis-9,trans-11 CLA & 0.57 & 0.72 & 0.121 & 0.27 \\
\hline trans-10, cis-12 CLA & 0.01 & 0.01 & 0.007 & 0.55 \\
\hline$\gamma$-Linolenic acid & 0.02 & 0.03 & 0.006 & 0.69 \\
\hline$\alpha$-Linolenic acid & 0.47 & 0.50 & 0.050 & 0.58 \\
\hline $20: 0$ & 0.16 & 0.15 & 0.006 & 0.11 \\
\hline $20: 2$ & 0.04 & 0.05 & 0.005 & 0.21 \\
\hline $20: 3$ & 0.11 & 0.12 & 0.009 & 0.23 \\
\hline $20: 4$ & 0.15 & 0.17 & 0.002 & 0.28 \\
\hline $22: 0$ & 0.05 & 0.05 & 0.002 & 0.19 \\
\hline$\Sigma \mathrm{SFA}$ & 63.9 & 60.9 & 1.956 & 0.19 \\
\hline$\Sigma$ MUFA & 28.0 & 30.2 & 1.547 & 0.23 \\
\hline$\Sigma$ PUFA & 1.37 & 1.59 & 0.160 & 0.22 \\
\hline$\Sigma$ trans $\mathrm{FA}$ & 3.92 & 5.07 & 1.000 & 0.31 \\
\hline Unknown & 3.40 & 3.92 & 0.163 & 0.03 \\
\hline
\end{tabular}

${ }^{1}$ TCNSL (technical-grade cashew nut shell liquid) $=30 \mathrm{~g} /$ cow per day.

${ }^{2} \mathrm{n}=15$ (n represents number of observations used in statistical analysis).

\section{CONCLUSIONS}

In this experiment, TCNSL (containing cardanol and cardol as main active ingredients, but no anacardic acids) had no effect on rumen methane emission in dairy cows, but tended to decrease it by $8 \%$ when expressed per kilogram of DMI. The product tended to increase total tract NDF digestibility, but had no effect on digestibility of the other dietary nutrients. Nitrogen excretion in urine and feces, bacterial composition of fecal matter, and antioxidative status of milk and plasma were not affected by TCNSL. Compared with the control, TCNSL decreased by $17 \%$ the concentration of C18:0 in milk fat.

\section{ACKNOWLEDGMENTS}

The authors thank Palmer International, Inc. (Skippack, PA) for providing the CNSL for the study, Ryan Elias' laboratory (Pennsylvania State University) for assisting with the oxidative stress marker analyses, Kevin Harvatine's laboratory (Pennsylvania State University) for conducting the milk FA analyses, D. Lomonaco (Universidade Federal do Ceara, Brazil) for 
Table 8. Oxidative status markers in milk and blood plasma of dairy cows fed a control or a TCNSL ${ }^{1}$ supplemented diet (LSM)

\begin{tabular}{|c|c|c|c|c|}
\hline Item & Control & TCNSL & $\mathrm{SEM}^{2}$ & $P$-value \\
\hline \multicolumn{5}{|l|}{ Milk } \\
\hline TBARS ${ }^{3} \mu \mathrm{L} /$ sample & 14.5 & 13.3 & 2.62 & 0.69 \\
\hline 8 -isoprostane, ${ }^{4} \mathrm{pg} / \mathrm{mL}$ & 1,003 & 1,031 & 313 & 0.85 \\
\hline TEAC, ${ }^{5}$ trolox equivalent, $\mu M$ & 6,360 & 7,131 & 430 & 0.14 \\
\hline \multicolumn{5}{|l|}{ Blood plasma } \\
\hline TBARS, $\mu \mathrm{L} /$ sample & 7.34 & 7.28 & 0.93 & 0.95 \\
\hline 8-isoprostane, $\mathrm{pg} / \mathrm{mL}$ & 25.1 & 26.9 & 2.11 & 0.43 \\
\hline TEAC ${ }^{4}$ trolox equivalent, $\mu M$ & 4,260 & 3,766 & 495 & 0.37 \\
\hline
\end{tabular}

${ }^{1}$ TCNSL (technical-grade cashew nut shell liquid) $=30 \mathrm{~g} /$ cow per day.

${ }^{2} \mathrm{n}=15$ (n represents number of observations used in statistical analysis).

${ }^{3}$ Thiobarbituric acid reactive substances.

${ }^{4}$ Statistical analysis was performed on log-transformed data.

${ }^{5}$ Trolox equivalent antioxidant capacity.

analyzing the TCNSL, and the staff of the Department of Animal Science, Pennsylvania State University Dairy Center for their conscientious care of the experimental cows.

\section{REFERENCES}

AOAC International. 2000. Official Methods of Analysis. 17th ed., AOAC International, Arlington, VA.

Bach Knudsen, K. E. B. 1997. Carbohydrate and lignin contents of plant materials used in animal feeding. Anim. Feed Sci. Technol. 67:319-338.

Boonsai, P., P. Phuwapraisirisan, and C. Chanchao. 2014. Antibacterial activity of a cardanol from Thai Apis mellifera propolis. Int. J. Med. Sci. 11:327-336.

Cao, G., and R. L. Prior. 1999. Measurement of oxygen radical absorbance capacity in biological samples. Methods Enzymol. 299:5062.

Caporaso, J. G., C. L. Lauber, W. A. Walters, D. Berg-Lyons, C. A. Lozupone, P. J. Turnbaugh, N. Fierer, and R. Knight. 2011. Global patterns of $16 \mathrm{~S}$ rRNA diversity at a depth of millions of sequences per sample. Proc. Natl. Acad. Sci. USA 108:4516-4522.

Chen, X. B., Y. K. Chen, M. F. Franklin, E. R. Orskov, and W. J. Shand. 1992. The effect of feed intake and body weight on purine derivative excretion and microbial protein supply in sheep. J. Anim. Sci. 70:1534-1542.

Coutinho, D. A., A. F. Branco, G. T. dos Santos, M. P. Osmari, A. L. Teodoro, and T. G. Diaz. 2014. Intake, digestibility of nutrients, milk production and composition in dairy cows fed on diets containing cashew nut shell liquid. Acta Sci. Anim. Sci. 36:311-316.

Danielsson, R., A. Werner-Omazic, M. Ramin, A. Schnürer, M. Griinari, J. Dicksved, and J. Bertilsson. 2014. Effects on enteric methane production and bacterial and archaeal communities by the addition of cashew nut shell extract or glycerol-An in vitro evaluation. J. Dairy Sci. 97:5729-5741.

Demeyer, D. I., and H. K. Henderickx. 1967. The effect of $\mathrm{C}_{18}$ unsaturated fatty acids on methane production in vitro by mixed rumen bacteria. Biochim. Biophys. Acta 137:484-497.

DeSantis, T. Z., P. Hugenholtz, N. Larsen, M. Rojas, E. L. Brodie, K. Keller, T. Huber, D. Dalevi, P. Hu, and G. L. Andersen. 2006. Greengenes, a chimera-checked 16S rRNA gene database and workbench compatible with ARB. Appl. Environ. Microbiol. 72:5069-5072.

Dijkstra, J., S. M. van Zijderveld, J. A. Apajalahti, A. Bannink, W. J. J. Gerrits, J. R. Newbold, H. B. Perdok, and H. Berends. 2011. Relationships between methane production and milk fatty acid profiles in dairy cattle. Anim. Feed Sci. Technol. 166-167:590-595.
El-Zaiat, H. M., R. C. Araujo, Y. A. Soltan, A. S. Morsy, H. Louvandini, A. V. Pires, H. O. Patino, P. S. Correa, and A. L. Abdalla. 2014. Encapsulated nitrate and cashew nut shell liquid on blood and rumen constituents, methane emission, and growth performance of lambs. J. Anim. Sci. 92:2214-2224.

Fievez, V., E. Colman, J. M. Castro-Montoya, I. Stefanov, and B. Vlaeminck. 2012. Milk odd- and branched-chain fatty acids as biomarkers of rumen function-An update. Anim. Feed Sci. Technol. 172:51-65.

Gellerman, J. L., N. J. Walsh, N. K. Werner, and H. Schlenk. 1969. Antimicrobial effects of anacardic acids. Can. J. Microbiol. 15:1219-1223.

Himejima, M., and I. Kubo. 1991. Antibacterial agents from the cashew Anacardium occidentale (Anacardiaceae) nut shell oil. J. Agric. Food Chem. 39:418-421.

Hristov, A. N., C. Lee, T. Cassidy, M. Long, K. Heyler, B. Corl, and R. Forster. 2011. Effects of lauric and myristic acids on ruminal fermentation, production, and milk fatty acid composition in lactating dairy cows. J. Dairy Sci. 94:382-395.

Hristov, A. N., J. Oh, J. Firkins, J. Dijkstra, E. Kebreab, G. Waghorn, H. P. S. Makkar, A. T. Adesogan, W. Yang, C. Lee, P. J. Gerber, B. Henderson, and J. M. Tricarico. 2013. Mitigation of methane and nitrous oxide emissions from animal operations: I. A review of enteric methane mitigation options. J. Anim. Sci. 91:5045-5069.

Hristov, A. N., M. Vander Pol, M. Angle, S. Zaman, C. Schneider, P. Ndegwa, V. K. Vaddella, K. Johnson, K. J. Shingfield, and S. K. R. Karnati. 2009. Effect of lauric acid and coconut oil on ruminal fermentation, digestion, ammonia losses from manure, and milk fatty acid composition in lactating cows. J. Dairy Sci. 92:55615582 .

Huhtanen, P., K. Kaustell, and S. Jaakkola. 1994. The use of internal markers to predict total digestibility and duodenal flow of nutrients in cattle given six different diets. Anim. Feed Sci. Technol. 48:211-227.

Kozubek, A., and J. H. P. Tyman. 1999. Resorcinolic lipids, the natural non-isoprenoid phenolic amphiphiles and their biological activity. Chem. Rev. 99:1-26.

Kubo, I., H. Muroi, M. Himejima, Y. Yamagiwa, H. Mera, K. Tokushima, S. Ohta, and T. Kamikawa. 1993. Structure-antibacterial activity relationship of anacardic acids. J. Agric. Food Chem. 41:1016-1019.

Lubi, M. C., and E. T. Thachil. 2000. Cashew nut shell liquid (CNSL)A versatile monomer for polymer synthesis. Des. Monomers Polym. 3:123-153. http://dx.doi.org/10.1163/156855500300142834.

Menon, A. R. R.. C. K. S. Pillai, J. D. Sudha, and A. G. Mathew. 1985. Cashew nut shell liquid-its polymeric and other industrial products. J. Sci. Ind. Res. (India) 44:324-338.

Mitsumori, M., O. Enishi, T. Shinkai, K. Higuchi, Y. Kobayashi, A. Takenaka, K. Nagashima, M. Mochizuki, and Y. Kobayashi. 2014 
Effect of cashew nut shell liquid on metabolic hydrogen flow on bovine rumen fermentation. Anim. Sci. J. 85:227-232.

NRC. 2001. Nutrient Requirements of Dairy Cattle. 7th rev. ed. Natl. Acad. Sci., Washington DC.

Rico, D. E., and K. J. Harvatine. 2013. Induction of and recovery from milk fat depression occurs progressively in dairy cows switched between diets that differ in fiber and oil concentration. J. Dairy Sci. 96:6621-6630.

Schneider, B. H., and W. P. Flatt. 1975. The evaluation of feeds through digestibility experiments. University of Georgia Press, Athens.

Shinkai, T., O. Enishi, M. Mitsumori, K. Higuchi, Y. Kobayashi, A. Takenaka, K. Nagashima, M. Mochizuki, and Y. Kobayashi. 2012. Mitigation of methane production from cattle by feeding cashew nut shell liquid. J. Dairy Sci. 95:5308-5316.

Sjaunja, L. O., L. Baevre, L. Junkkarinen, J. Pedersen, and J. Setälä. 1990. A Nordic proposal for an energy-corrected milk (ECM) formula. Pages 156-157 in 27th Session of the International Commission for Breeding and Productivity of Milk Animals, Paris, France. Wageningen Academic Publishers, Wageningen, the Netherlands.

Stasiuk, M., and A. Kozubek. 2010. Biological activity of phenolic lipids. Cell. Mol. Life Sci. 67:841-860.

Trevisan, M. T. S., B. Pfundstein, R. Haubner, G. Würtele, B. Spiegelhalder, H. Bartsch, and R. W. Owen. 2006. Characterization of alkyl phenols in cashew (Anacardium occidentale) products and assay of their antioxidant capacity. Food Chem. Toxicol. 44:188 197.

Tyman, J. H. P., D. Wilczynski, and M. A. Kashani. 1978. Compositional studies on technical cashew nutshell liquid (CNSL) by chromatography and mass spectroscopy. J. Am. Chem. Soc. 55:663-668.

Valadares, R. F. D., G. A. Broderick, S. C. Valadares Filho, and M. K. Clayton. 1999. Effect of replacing alfalfa silage with high moisture corn on ruminal protein synthesis estimated from excretion of total purine derivatives. J. Dairy Sci. 82:2686-2696.

van Lingen, H. J., L. A. Crompton, W. H. Hendriks, C. K. Reynolds, and J. Dijkstra. 2014. Meta-analysis of relationships between enteric methane yield and milk fatty acid profile in dairy cattle. J. Dairy Sci. 97: http://dx.doi.org/10.3168/jds.2014-8268 ((article in press).

Van Nevel, C. J., D. I. Demeyer, and H. K. Henderickx. 1971. Effect of fatty acid derivatives on rumen methane and propionate in vitro. Appl. Microbiol. 21:365-366.

Van Soest, P. J., J. B. Robertson, and B. A. Lewis. 1991. Methods for dietary fiber, neutral detergent fiber, and nonstarch polysaccharides in relation to animal nutrition. J. Dairy Sci. 74:3583-3597.

Vlaeminck, B., V. Fievez, A. R. J. Cabrita, A. J. M. Fonseca, and R. J. Dewhurst. 2006. Factors affecting odd- and branched-chain fatty acids in milk: A review. Anim. Feed Sci. Technol. 131:389-417.

Voirin, C., S. Caillol, N. V. Sadavarte, B. V. Tawade, B. Boutevinab, and P. P. Wadgaonkar. 2014. Functionalization of cardanol: towards biobased polymers and additives. Polym. Chem. 5:31423162 .

Watanabe, Y., R. Suzuki, S. Koike, K. Nagashima, M. Mochizuki, R. J. Forster, and Y. Kobayashi. 2010. In vitro evaluation of cashew nut shell liquid as a methane-enhancing agent for ruminants. J. Dairy Sci. 93:5258-5267.

Wolfe, R. S. 1991. My kind of biology. Annu. Rev. Microbiol. 45:1-35.

Yoon, D.-Y., and D.-S. Kim. 2009. Molecular design of anti-biofouling materials from natural phenolic compounds. Korean J. Chem. Eng. 26:433-437.

Zimmerman, P., S. Zimmerman, S. Utsumi, and D. Beede. 2011. Development of a user-friendly online system to quantitatively measure metabolic gas fluxes from ruminants. J. Dairy Sci. 94(ESuppl. 1):760. (Abstr.) 